\title{
PEMBUATAN DAN KARAKTERISASI MEMBRAN FOTOKATALITIK HOLLOW FIBER SELULOSA ASETAT-TiO 2 UNTUK DEGRADASI REMAZOL RED 198
}

\author{
Siti Wafiroh*, Mevitri Rahmiati, Pratiwi Pudjiastuti \\ Departemen Kimia, Fakultas Sains dan Teknologi \\ Universitas Airlangga \\ *email : sitiwafiroh@unair.ac.id
}

Received 1 April 2018

Accepted 2 Mei 2018

\begin{abstract}
Abstrak
Telah dilakukan sintesis dan karakterisasi membran fotokatalitik hollow fiber selulosa asetat- $\mathrm{TiO}_{2}$ untuk degradasi remazol red 198. Membran hollow fiber dibuat dengan metode inversi fasa menggunakan larutan dope dengan perbandingan komposisi selulosa asetat, aseton, dan formamida $(22,51$, dan $27 \%)$. Kemudian $\mathrm{TiO}_{2}$ ditambahkan dengan variasi konsentrasi 0,10, 0,15,0,20,0,25, dan 0,30\% (b/b). Karakterisasi membran hollow fiber meliputi uji ketebalan, uji mekanik, uji kinerja dan efisiensi membran fotokatalitik hollow fiber untuk degradasi remazol red 198. Dari hasil penelitian diperoleh membran hollow fiber selulosa asetat- $\mathrm{TiO}_{2}$ yang optimum pada penambahan $\mathrm{TiO}_{2}$ sebesar $0,25 \%$. Membran hollow fiber selulosa asetat-TiO ${ }_{2}$ yang optimum mempunyai sifat mekanik yaitu : ketebalan membran $0,1433 \mathrm{~mm}$, nilai tegangan $502,74 \mathrm{kN} / \mathrm{m}^{2}$ nilai regangan $0,133 \mathrm{dan}$ modulus young $4781,13 \mathrm{kN} / \mathrm{m}^{2}$. Kinerja membran fotokatalitik hollow fiber dengan umpan remazol red mempunyai nilai fluks $17,41 \mathrm{~L} / \mathrm{m}^{2}$ jam dan rejeksi $91,8 \%$. Efisiensi degradasi membran selulosa asetat- $\mathrm{TiO}_{2}$ terhadap remazol red 198 murni sebesar 92,43\% sedangkan efisiensi degradasi membran selulosa asetat- $\mathrm{TiO}_{2}$ terhadap limbah tekstil sebesar $81,77 \%$.
\end{abstract}

Katakunci: Membran hollow fiber, selulosa asetat, fotokatalitik, $\mathrm{TiO}_{2}$, remazol red 198

\begin{abstract}
This done synthesis and to characterize cellulosa acetate (CA)- $\mathrm{TiO}_{2}$ hollow fiber photocatalytic membrane for degradation remazol red 198. Hollow fiber membrane is made by phase inversion method using dope solution with composition ratio of cellulose acetate, acetone, and formamide (22, 51 and $27 \%$ respectively). $\mathrm{TiO}_{2}$ was then added with various concentration $0.10,0.15,0.20,0.25$ and $0.30 \%$ (w/w). Characterization of hollow fiber membrane membrane are strain, stress, youth modulus, flux test, rejection, SEM test, FT IR test and efficiency degradation for remazol red 198. The result show that optimum concentration of $\mathrm{TiO}_{2}$ addition was $0.25 \%$. The optimum hollow fiber membrane cellulose acetate- $\mathrm{TiO}_{2}$ was consist of thickness, strain, stress and modulus Young $0.1433 \mathrm{~mm}, 502.74$ $\mathrm{kN} / \mathrm{m}^{2}$, and $4781.13 \mathrm{kN} / \mathrm{m}^{2}$, respectively. The performance of the hollow fiber photocatalytic membrane with the red remazol feed has a flux value of $17.41 \mathrm{~L} / \mathrm{m}^{2} \cdot \mathrm{h}$ and rejection of $91.8 \%$. The efficiency of degradation of cellulose acetate- $\mathrm{TiO}_{2}$ membrane to pure red remazol 198 is $92.43 \%$ while degradation efficiency of cellulose acetate- $\mathrm{TiO}_{2}$ membrane to textile waste is $81.77 \%$.
\end{abstract}

Keywords: hollow fiber membrane, cellulose acetate, photocatalytic, $\mathrm{TiO}_{2}$, remazol red 198 


\section{Pendahuluan}

Pada industri tekstil, industri kerajinan batik memerlukan banyak air dalam proses pencelupan dan pencuciannya. Industri kerajinan batik didominasi oleh industri skala kecil menengah (Karmanto, 2014). Pencemaran air pada industri kerajinan batik diperoleh dari proses pewarnaan pada batik karena menggunakan pewarna organik. Limbah zat warna tersebut dapat mencemari perairan karena merupakan senyawa organik yang tidak dapat terurai secara langsung. Proses pewarnaan batik selain menggunakan zat warna juga menggunakan zat pembantu seperti soda kostik atau natrium hidroksida, soda abu, asam klorida, asam sulfat dan tawas (Sukarta, 2013). Limbah zat warna yang langsung dibuang ke perairan dapat mempengaruhi aktivitas fotosintesis di perairan, karena cahaya matahari yang masuk menjadi berkurang. Zat warna juga dapat mengubah warna cahaya tampak sebagai akibat absorpsi selektif terhadap panjang gelombang tertentu (Singh. at.al, 2011).

Zat warna yang sering digunakan pada industri tesktil adalah zat warna golongan azo. Zat warna golongan azo masuk ke dalam golongan limbah yang sulit terdegradasi oleh mikroorganisme. Zat warna golongan azo pada kadar dan jenis tertentu bersifat karsinogenik dan toksik, namun dapat bersifat non toksik pada kadar rendah (Xu, at al., 2012). Remazol red 198 termasuk dalam zat warna azo yang biasa digunakan untuk pewarnaan pada industri batik. Remazol red 198 merupakan zat warna reaktif berbentuk serbuk, padat, berwarna merah kecoklatan, dan larut dalam air (Bazrafshan at.al, 2013).

Degradasi senyawa remazol red 198 dapat menggunakan metode Advanced Oxidation Processes (AOP). AOP merupakan metode yang menggunakan prinsip/proses oksidasi yang dapat mendegradasi senyawa-senyawa pencemar dalam limbah industri (Villar, et al. 2015). Pada metode ini akan dihasilkan suatu radikal hidroksil $(\mathrm{OH})$. Radikal hidroksil tersebut yang mendegradasi pencemar yang berupa senyawa organik. Dari metode tersebut diperoleh hasil dekolorisasi mencapai $100 \%$ selama 60 menit, namun pada proses ini masih memiliki kekurangan yaitu harus memisahkan antara katalis yang tersuspensi dengan larutannya.

Degradasi zat warna remazol red 198 juga dapat menggunakan selulosa bacterial. Bahan baku selulosa bacterial dari nata de coco dengan penambahan nanopartikel $\mathrm{ZnO}$ sebagai fotokatalis terimmobilisasi untuk membentuk serat hollow. Serat hollow dihasilkan dari proses wet spinning menggunakan koagulan $\mathrm{NaOH}$. Proses dekolorisasi fotokatalitik terhadap air limbah tekstil artifisial yang mengandung zat warna reaktif remazol black 5 (RB5) menghasilkan persen penyisihan warna tertinggi yaitu $90,32 \%$ (Verma, at.al. 2012).

Membran merupakan alternatif terbaik untuk membantu proses pengolahan air (water treatment) karena lebih sederhana dan murah. Salah satu jenis membran yang digunakan untuk proses pengolahan air yaitu membran hollow fiber. Membran hollow fiber adalah membran buatan yang mengandung penghalang semipermeabel dalam bentuk serat berongga (Mezohegyi et al., 2012). Membran hollow fiber banyak digunakan dalam proses industri, limbah industri dan pengolahan minuman dan sangat cocok digunakan untuk pengolahan air limbah. Saat ini banyak dikembangkan pengolahan limbah tekstil menggunakan fotokatalitik yang dikompositkan dengan $\mathrm{TiO}_{2}$. Bahan organik untuk pembuatan membran umumnya menggunakan selulosa asetat, poliamida, polisulfon (Wenten I. G, 2014).

Penelitian ini menggunakan selulosa asetat untuk bahan utama pembuatan membran hollow fiber dan dikompositkan dengan $\mathrm{TiO}_{2}$ yang diaplikasikan untuk pengelolaan limbah zat warna remazol red 198. Metode yang digunakan adalah metode inversi fasa. Pembuatan membran 
hollow fiber selulosa asetat dengan komposisi selulosa asetat $22 \%$, aseton $51 \%$ dan formamida $27 \%$. Pada pembuatan membran hollow fiber selulosa asetat dilakukan variasi konsentrasi pada $\mathrm{TiO}_{2}$ 0,10, 0,15, 0,20, 0,25, dan 0,30\%. Membran yang dihasilkan akan dikarakterisasi dengan uji mekanik, uji kinerja. Membran hollow fiber selulosa asetat juga diuji morfologinya dan gugus fungsinya

\section{Metode Penelitian}

Alat dan bahan

Peralatan yang digunakan dalam penelitian ini meliputi seperangkat alat cetak membran hollow fiber skala laboratorium, neraca digital, magnetik stirer, mikrometer sekrup, Autograph AG10 TE Shimadzu, spektrofotometer UVVis Shimadzu 1800, Scanning Electron Microscopy (SEM), spektofotometer Fourier Transform Infra Red (FT-IR) Bruke Tensor 27 dan peralatan gelas yang biasa digunakan. Bahan yang digunakan dalam penelitian ini adalah limbah industry tekstil dalam keadaan fresh mengandung remazol red 198. Bahan kimia yang digunakan antara lain selulosa asetat (SA), aseton, formamida, $\mathrm{TiO}_{2}$.

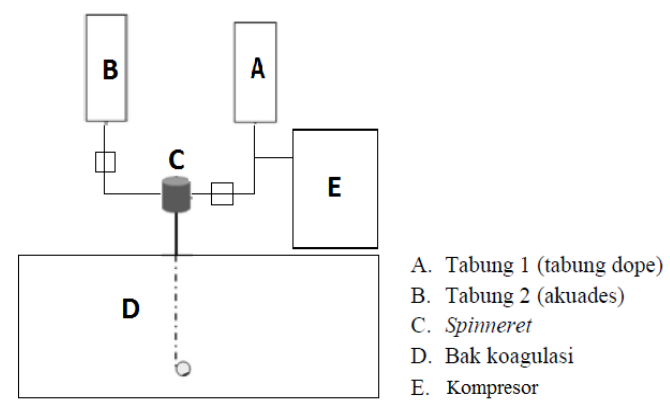

Gambar 1. Skema alat pencetak membran hollow fiber

Pembuatan membran fotokatalitik hollow fiber selulosa asetat-TiO

Pembuatan membran hollow fiber diawali dengan membuat dope larutan membran yang terdiri dari: selulosa asetat, aseton dan formamida yang digunakan memiliki perbandingan $22 \%, 51 \%$, dan 27\%. Komposisi $\mathrm{TiO}_{2}$ yang digunakan dibuat dengan variasi konsentrasi yaitu $0,10, \quad 0,15, \quad 0,20, \quad 0,25$ dan $0,30 \%$ ditambahkan dengan mengurangi komposisi selulosa asetat. Setelah homogen, dope membrane dicetak dengan metode inversi fasa pada alat cetak membran seperti ditunjukkan Gambar 1. Bak koagulan yang berisi es yang mempunyai suhu kurang dari $5^{0} \mathrm{C}$ dan diletakkan dibawah spinneret sejauh 25 $\mathrm{cm}$. Larutan dope dimasukkan dalam tabung 1 (tabung dope). Pada tabung 2 dialirkan akuades dengan mengatur flowmeter. Tabung 1 yang berisi larutan dope dihubungkan dengan kompresor menggunakan selang. Kemudian keran air dan kompresor dibuka untuk memulai proses pembentukan membran hollow fiber. Setelah melewati spinneret, larutan dope masuk ke dalam bak koagulan sehingga membentuk hollow fiber yang padat. Membran fotokatalitik hollow fiber yang padat dicuci dengan air mengalir yang bertujuan untuk menghilangkan sisa pelarut. Setelah itu dimasukkan dalam bak yang berisi larutan natrium azida sampai hollow fiber dikarakterisasi (Bayazit at.al., 2014).

Uji mekanik membran fotokatalitik hollow fiber selulosa asetat-TiO

Uji mekanik membran fotokatalitik hollow fiber dilakukan dengan cara uji tarik. Dari data yang diperoleh, dapat menentukan nilai stress $(\sigma)$, strain $(\varepsilon)$, dan modulus Young (E) dari persamaan 1, 2 dan 3 dengan gaya (F), pertambahan panjang $(\Delta L)$, panjang awal $\left(L_{0}\right)$, dan luas penampang $(A)$.

$$
\begin{gathered}
\sigma=\frac{F}{A} \\
\varepsilon=\frac{\Delta L}{L_{0}} \\
\mathrm{E}=\frac{\sigma}{\varepsilon}
\end{gathered}
$$

Penentuan kinerja Membran Fotokatalitik Hollow Fiber Selulosa Asetat-TiO

Penentuan kinerja membran fotokatalitik hollow fiber dilakukan 
dengan mengukur fluks dan rejeksi. Pertama tama membran fotokatalitik hollow fiber dibentuk menjadi modul sebelum dilakukan uji fluks. Kemudian dikompaksi pada tekanan 2 atm dengan mengalirkan air yang melewati membran sebelum digunakan untuk pemisahan remazol red 198. Setelah dikompaksi maka dilakukan pengukuran nilai fluks dengan mengukur volume yang ditampung dalam selang waktu tertentu. Setelah nilai fluks konstan aliran air digantikan dengan aliran larutan remazol red 198 dan limbah cair pewarna tekstil yang masing masing diambil $200 \mathrm{~mL}$ kemudian difiltrasi pada membran fotokatalitik hollow fiber selulosa asetat- $\mathrm{TiO}_{2}$. Setelah itu, dari data yang diperoleh dapat dihitung nilai fluks. Nilai rejeksi dapat dihitung dengan mengukur konsentrasi remazol red 198 sebelum dan sesudah melewati membran dengan alat spektrofotometer UV Vis (Lestari, 2013).

Morfologi membran fotokatalitik hollow fiber selulosa asetat-TiO

Penentuan morfologi membran fotokatalitik hollow fiber dilakukan dengan cara uji SEM (Scanning Electron Microscopy). Membran hollow fiber terlebih dahulu direndamkan pada nitrogen cair agar mengeras. Membran hollow fiber dipotong. Selanjutnya dilakukan pengambilan gambar dan pembesaran 1250-1500X pada permukaan dan penampang melintang membran dengan menggunakan SEM.

Penentuan gugus fungsi membran hollow fiber selulosa asetat-TiO ${ }_{2}$

Penentuan gugus fungsi membran hollow fiber dilakukan dengan uji FT-IR (Forier Transform Infra Red) Bruke Tensor 27. Sebanyak 1mg membran hollow fiber dicampurkan dengan $100 \mathrm{mg}$ $\mathrm{KBr}$. Campuran tersebut dibentuk menjadi lapisan tipis transparan kemudian dimasukan dalam pellet dan ditekan. Pada bilangan 4000-400 $\mathrm{cm}^{-1}$ dilakukan perekaman
Membran fotokatalitik hollow fiber selulosa asetat-TiO ${ }_{2}$ untuk degradasi remazol red 198

Aplikasi membran fotokatalitik hollow fiber selulosa asetat- $\mathrm{TiO}_{2}$ untuk degradasi remazol red 198 menggunakan alat spektrofotometer UV-Vis Shimadzu dan reaktor fotokatalitik. Larutan limbah remazol red 198 dari pabrik tekstil disaring dengan menggunakan kertas saring Whatmann ukuran 42. Larutan remazol red 198 yang telah disaring diambil $10 \mathrm{~mL}$ dan diukur absorbansi awal pada panjang gelombang maksimum. Kemudian larutan remazol red 198 diambil $200 \mathrm{~mL}$ dan dikontakkan pada membran fotokatalitik hollow fiber selulosa asetat- $\mathrm{TiO}_{2}$ yang optimum disinari lampu UV selama 3 jam. Larutan remazol red 198 yang sudah dikontakkan diukur kembali menggunakan spektrofotometer UV-Vis untuk mengetahui absorbansinya. Hasil limbah yang sudah dikontakkan pada reaktor dijadikan umpan untuk filtrasi cross-flow dengan dilewatkan pada membran hollow fiber selulosa asetat-TiO 2 . Permeat hasil filtrasi diukur absorbansinya untuk mengetahui konsentrasi akhir limbah. Data yang diperoleh digunakan untuk mengetahui efisiensi degradasi limbah dan pewarna murni membran selulosa asetat$\mathrm{TiO}_{2}$ dengan fotokatalitik dan dibandingkan dengan $\mathrm{TiO}_{2}$.

\section{Hasil dan Pembahasan \\ Membran fotokatalitik hollow fiber selulosa asetat-TiO}

Pembuatan membran hollow fiber diawali dengan membuat dope larutan membran. Larutan dope membran selulosa asetat yang terbentuk tidak berwarna, kental dan homogen. Pada penelitian ini digunakan komposisi selulosa asetat : aseton : formamida sebesar 22\%: $51 \%$ : $27 \%$. Setelah penambahan $\mathrm{TiO}_{2}$ larutan dope menjadi berwarna putih dan kental dengan variasi konsentrasi $\mathrm{TiO}_{2}$ yaitu $0,10,0,15$, $0,20,0,25 \%$ dan $0,30 \%(b / b)$. Semakin banyak penambahan $\mathrm{TiO}_{2}$ maka larutan dope yang dihasilkan juga semakin kental. 
Pada saat dope akan dicetak, kran air dan kompresor dinyalakan bersamaan sehingga bersama-sama keluar menuju spinneret. Larutan dope yang keluar dari spinneret akan mengalir ke bak koagulan yang mempunyai suhu dibawah $5^{\circ} \mathrm{C}$. Membran hollow fiber yang masuk pada bak koagulan yang mempunyai suhu rendah akan membuat pori membran menjadi asimetrik (ukuran pori luar dan pori dalam berbeda) dan menyebabkan permeselektivitasnya tinggi karena pertukaran inversi fasa lambat dan proses difusi juga lambat pada suhu rendah. Membran yang sudah terbentuk direndam pada larutan natrium azida sebelum dikarakterisasi untuk mencegah degradasi membran oleh bakteri. Membran hollow fiber selulosa asetat- $\mathrm{TiO}_{2}$ kemudian dibuat modul seperti pada Gambar 2.

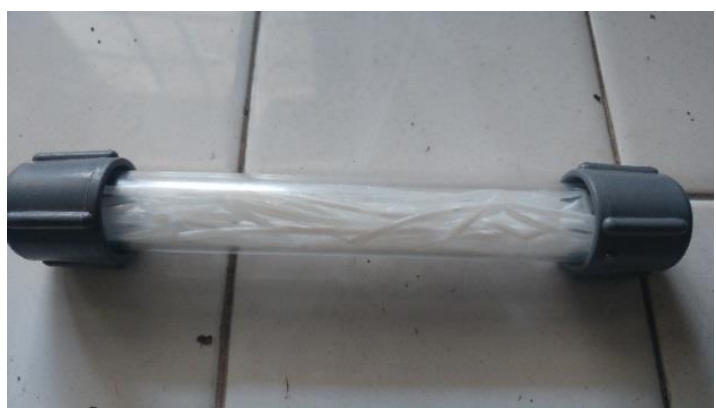

Gambar 2. Modul membran hollow fiber selulosa asetat- $\mathrm{TiO}_{2}$

Sifat mekanik membran fotokatalitik hollow fiber selulosa asetat-TiO ${ }_{2}$

Dari hasil uji tarik diperoleh data nilai tegangan pada setiap variasi konsentrasi $\mathrm{TiO}_{2}$. Tegangan atau kuat tarik didefinisikan sebagai perbandingan antara gaya yang bekerja pada benda dengan luas penampang benda (Baker, 2004). Pada gambar 3, diperoleh nilai tegangan maksimal sebesar $502,739 \mathrm{kN} / \mathrm{m}^{2}$ terdapat pada variasi konsentrasi $\mathrm{TiO}_{2} 0,25 \%$.

Regangan adalah perbandingan pertambahan panjang luar pada membran dengan panjang awal. Semakin besar penambahan konsentrasi $\mathrm{TiO}_{2}$ maka regangan akan semakin kecil. Konsentrasi $\mathrm{TiO}_{2}$ yang bertambah menyebabkan bertambahnya pula jumlah molekul dan menyebabkan semakin banyak ikatan antar molekul. Nilai regangan naik pada konsentrasi $\quad \mathrm{TiO}_{2} \quad 0,25 \%$. Jumlah konsentrasi $\mathrm{TiO}_{2}$ yang bertambah menyebabkan kelarutan semakin lama. Nilai modulus Young tergantung pada jenis bahan yang digunakan. Modulus young dapat diartikan ukuran kekakuan suatu bahan. Nilai modulus Young membran besar maka membran dapat mempertahankan ukuran pori ketika diaplikasikan pada tekanan yang besar

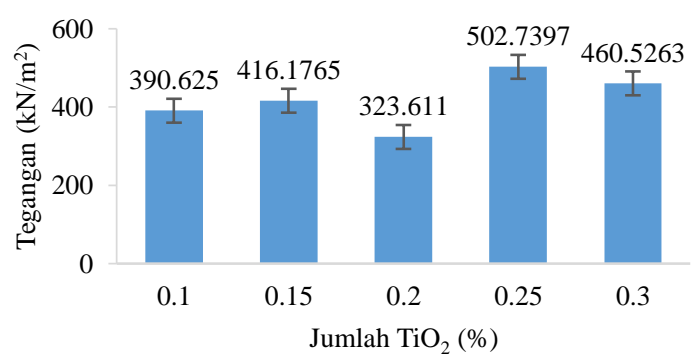

Gambar 3. Grafik tegangan terhadap variasi konsentrasi $\mathrm{TiO}_{2}$

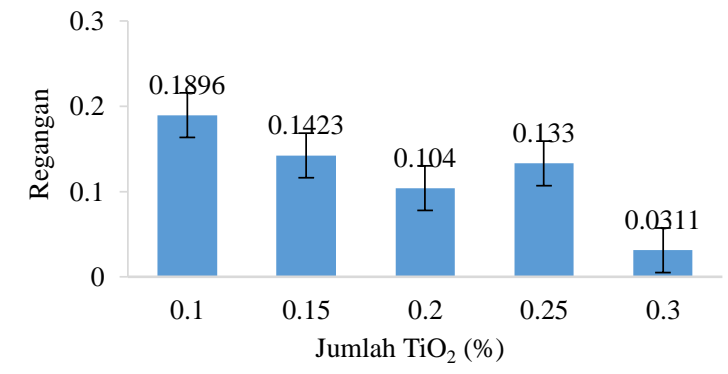

Gambar 4. Grafik nilai regangan pada variasi penambahan $\mathrm{TiO}_{2}$.

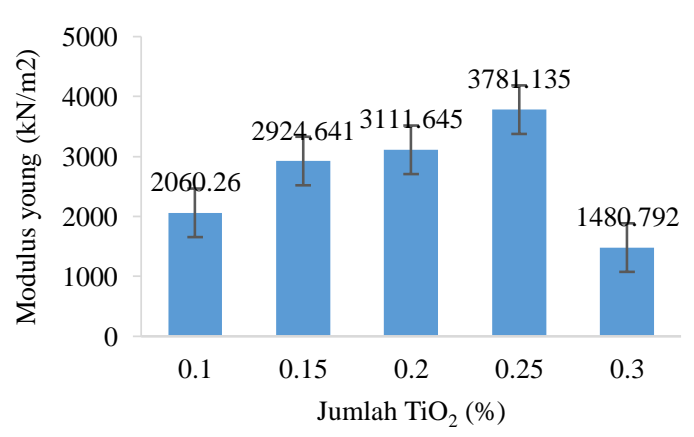

Gambar 5. Grafik modulus Young terhadap variasi konsentrasi $\mathrm{TiO}_{2}$

Dari keselurahan data uji mekanik membran hollow fiber yang mempunyai sifat mekanik optimal adalah membran dengan variasi konsentrasi $\mathrm{TiO}_{2}$ sebesar 
$25 \%$ dengan nilai tegangan 502,7397 $\mathrm{kN} / \mathrm{m}^{2}$, nilai regangan 0,133 dan nilai modulus Young sebesar 4781,135 kN/m².

Kinerja membran fotokatalitik hollow fiber selulosa asetat-TiO ${ }_{2}$

Uji kinerja pada membran hollow fiber meliputi uji fluks dan rejeksi. Uji kinerja dilakukan untuk mengetahui kinerja membran dalam proses pengolahan limbah zat pewarna remazol red 198. Fluks merupakan jumlah permeat yang melewati membran persatuan waktu. Harga fluks menunjukan kecepatan alir permeat saat melewati membran dan dipengaruhi oleh jumlah pori-pori membran (Mulder, 2000). Sedangkan koefisien rejeksi merupakan kemampuan membran menahan zat terlarut.

Untuk mengetahui uji kinerja membran hollow fiber selulosa asetat- $\mathrm{TiO}_{2}$ pertama dilakukan kompaksi terlebih dahulu. Kompaksi dilakukan dengan cara mengalirkan air pada membran untuk membuat pori-pori membran terbuka sampai dengan volume konstan. Membran hollow fiber yang sudah dicetak dibentuk modul seperti pada gambar. Setelah dikompaksi, limbah cair dan remazol red 198 dialirkan pada membran hollow fiber selulosa asetat- $\mathrm{TiO}_{2}$. Untuk menghitung konsentrasi selama uji, digunakan spektofotometer UV-Vis. Setelah dialiri limbah dan zat warna tekstil diperoleh fluks membran fotokatalitik hollow fiber selulosa asetat- $\mathrm{TiO}_{2}$ terhadap remazol red 198 sebesar $17,41 \mathrm{~L} / \mathrm{m}^{2}$ jam dan nilai koefisien rejeksi sebesar 91,8\%. Uji kinerja membran hollow fiber selulosa asetat- $\mathrm{TiO}_{2}$ terhadap limbah cair diperoleh fluks sebesar $20,04 \mathrm{~L} / \mathrm{m}^{2}$ jam. dan nilai koefisien rejeksi sebesar 82,69\%.

Morfologi membran fotokatalitik hollow fiber selulosa asetat-TiO

Morfologi membran hollow fiber menggunakan SEM (Scanning Electron Microscopy) digunakan untuk mengetahui bentuk permukaan membran dan penampang melintang membran hollow fiber selulosa asetat- $\mathrm{TiO}_{2}$ seperti ditunjukkan pada Gambar 6.

Pada permukaan luar membran hollow fiber selulosa asetat- $\mathrm{TiO}_{2}$ dilakukan pada perbesaran 1730X, pada permukaan membran terlihat pori-pori dan distribusi pori-pori membran yang merata, tetapi pada penampang lintang porinya tidak sesuai harapan yang harusnya membentuk pori yang asimetris.

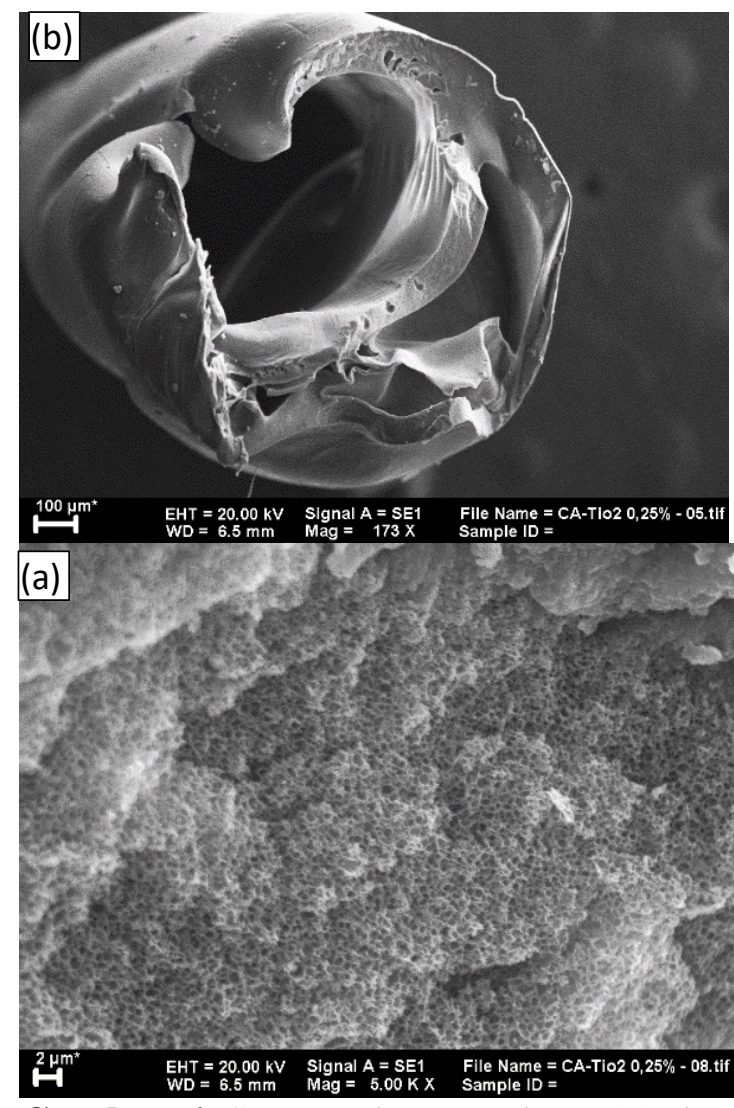

Gambar 6. SEM pada permukaan (a) dan penampang melintang (b) membran hollow fiber selulosa asetat- $\mathrm{TiO}_{2}$

Gugus fungsi membran fotokatalitik hollow fiber selulosa asetat-TiO

Karakterisasi FT-IR dilakukan untuk menganalisa adanya gugus fungsi baru pada membran hollow fiber selulosa asetat setelah ditambahkan $\mathrm{TiO}_{2}$. Hasil spektrum FT-IR membran selulosa asetat dan membran selulosa asetat- $\mathrm{TiO}_{2}$ ditunjukkan pada gambar 7. Pada hasil spektrum membran hollow fiber selulosa asetat dan spektrum membran hollow fiber selulosa asetat- $\mathrm{TiO}_{2}$ relatif tidak memiliki 
perbedaan yang berarti. Adanya serapan bilangan gelombang $528,4 \mathrm{~cm}^{-1}$ pada membran selulosa asetat- $\mathrm{TiO}_{2}$ disebabkan adanya gugus Ti-O. Hal ini menunjukkan bahwa tidak ada ikatan yang terjadi antara membran hollow fiber selulosa asetat dengan $\mathrm{TiO}_{2}$. Rentang bilangan gelombang serapan Ti-O dari $\mathrm{TiO}_{2}$ yaitu $550-700 \mathrm{~cm}^{-1}$ (daerah fingerprint) (Nakamoto, 2009) dan Samira (2012) rentang panjang gelombang serapan $\mathrm{TiO}_{2}$ yaitu pada daerah bilaangan gelombang $479-625 \mathrm{~cm}^{-1}$.

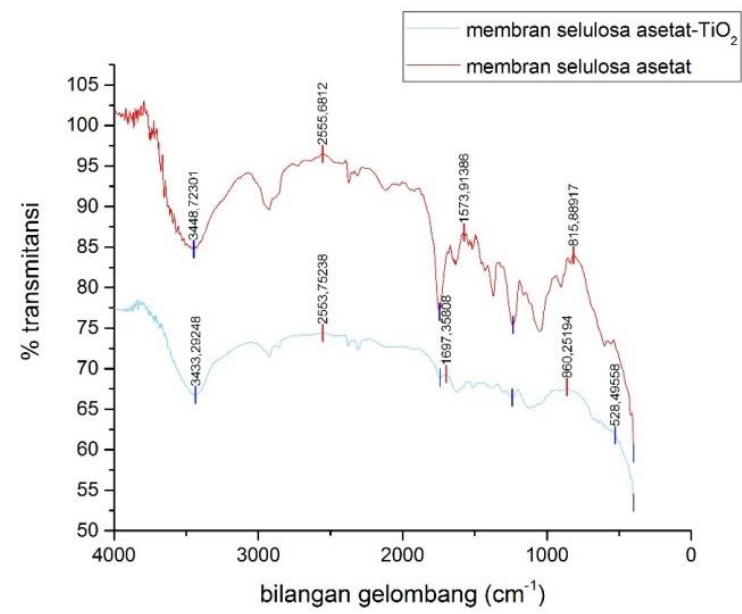

Gambar 7. Hasil spektrum FT-IR membran selulosa asetat dan membran selulosa asetat$\mathrm{TiO}_{2}$

Aplikasi membran fotokatalitik hollow fiber selulosa asetat-TiO

Aplikasi membran fotokatalitik hollow fiber selulosa asetat- $\mathrm{TiO}_{2}$ dilakukan dengan memfiltrasi membran ke dalam reaktor fotokatalitik. Membran hollow fiber yang telah direaktor diukur absorbansinya kemudian dbandingkan dengan hasil reaktor $\mathrm{TiO}_{2}$ untuk mengetahui keefektifan membran hollow fiber selulosa asetat- $\mathrm{TiO}_{2}$ dalam mendegradasi limbah cair maupun zat warna. Membran hollow fiber selulosa asetat- $\mathrm{TiO}_{2}$ dan $\mathrm{TiO}_{2}$ yang sudah direaktor diukur absorbansi untuk mengetahui hasil akhir konsentrasi. Preparasi dilakukan dengan menyaring limbah dengan kertas saring Whatman 42 agar partikel yang tidak diinginkan tidak ikut tersaring yang dapat merusak pori-pori membran hollow fiber. Limbah cair dan remazol red 198 diukur absorbansinya menggunakan spektrofotometer UV-Vis dengan panjang gelombang 525,5 nm.

Degradasi limbah cair terhadap $\mathrm{TiO}_{2}$ dilakukan dengan cara memasukan serbuk $\mathrm{TiO}_{2}$ kedalam gelas beker yang sudah terisi limbah cair kemudiandimasukkan dalam reaktor dan distirer. Stirer digunakan untuk pengadukan selama proses dikontakkan dalam reaktor selama 3 jam. Limbah cair mempunyai absorbansi mula-mula sebesar 0,327 dengan konsentrasi sebsar 2,71 ppm. Setelah dikontakkan dalam reaktor, limbah yang asalnya berwarna coklat berubah menjadi coklat muda. Dalam gelas beker terdapat 2 layer, serbuk $\mathrm{TiO}_{2}$ berada didasar gelas beker sedangkan lmbah cair berada di atas $\mathrm{TiO}_{2}$. Limbah cair yang sudah didegradasi diukur absorbansinya sehingga diperoleh absorbansi sebesar 0,073 dengan konsentrasi sebesar $0,316 \mathrm{ppm}$ maka diperoleh \% degradasi sebesar 88,34\%. Degradasi limbah cair pewarna tekstil terhadap membran selulosa asetat- $\mathrm{TiO}_{2}$ dilakukan dengan cara modul membran dimasukkan dalam gelas beker yang berisi limbah cair dan difiltrasikan dalam reaktor selama 3 jam. Absorbansi limbah cair mula mula sebesar 0,327 dengan konsentrasi sebesar 2,71 ppm. Setelah dikontakkan dalam reaktor, membran selulosa asetat$\mathrm{TiO}_{2}$ yang awalnya berwarna putih berubah menjadi coklat pada bagian bawah yang dicelupkan ke dalam limbah cair dan limbah zat warna berubah menjadi coklat muda. Membran yang sudah dikontakkan diukur absorbansinya dan didapatkan absorbansi sebesar 0,092 dengan konsentrasi sebesar 0,494 ppm maka diperoleh \% degradasi sebesar $81,77 \%$.

Degradasi remazol red 198 terhadap $\mathrm{TiO}_{2}$ dilakukan dengan cara yang sama seperti degradasi limbah zat warna terhadap $\mathrm{TiO}_{2}$. Larutan remazol red 198 yang sudah dicampurkan dengan $\mathrm{TiO}_{2}$ distirer dan dikontakkan kedalam reaktor selama 3 jam. Absorbansi larutan remazol red 198 mula-mula 0,231 ppm dengan 
konsentrasi $1,80 \mathrm{ppm}$. Setelah campuran tersebut dikontakkan terdapat 2 layer pada gelas beker yaitu larutan remazol red 198 di bagian atas dan $\mathrm{TiO}_{2}$ di bagian bawah. $\mathrm{TiO}_{2}$ yang dimasukan kedalam larutan remazol red 198 tidak larut ketika dikontakkan dalam reaktor sehingga terbentuk 2 lapisan. $\mathrm{TiO}_{2}$ yang tidak larut dalam larutan remazol red 198 dipisahkan dengan kertas saring dan diukur absorbansinya. Absorbansi larutan remazol red 198 setelah didegradasi sebesar 0,048 sehingga didapatkan konsentrasi sebesar $0,080 \mathrm{ppm}$ maka diperoleh \% degradasi sebesar 95,56\%. Degradasi remazol red 198 terhadap membran hollow fiber selulosa asetat- $\mathrm{TiO}_{2}$ dilakukan dengan cara modul membran dimasukan ke dalam gelas beker yang berisi larutan remazol red 198. Modul membran difiltrasikan ke dalam gelas beker dan dikontakkan pada reaktor selama 3 jam. Larutan remazol red 198 mula-mula mempunyai absorbansi sebesar 0,231 dengan konsentrasi 1,80 ppm. Setelah dikontakkan, membran hollow fiber selulosa asetat- $\mathrm{TiO}_{2}$ yang awalnya berwarna putih berubah menjadi warna pink pada bagian bawah yang dicelupkan ke dalam larutan remazol red 198 dan larutan remazol red 198 berubah menjadi pink muda. Setelah membran dikontakkan, larutan remazol red 198 diukur absorbansinya dan diperoleh absorbansi

\section{Daftar Pustaka}

Baker, R. W., 2004, Membrane Technology and Applications Second Edition, John Wiley and Sons Ltd., California, 133-139.

Bayazit, S.S., Kerkez, O., 2014. Hexavalent Chromium Adsorption on Superparamagnetic Multi-Wall Carbon Nanotubes and Activated Carbon Composites.

Bazrafshan, E., Mostafapour, F.K., 2013, Decolorization of Reactive red 198 by Adsorption onto $\mathrm{ZnCl}_{2}$ Activated Karbon sebesar 0,054 dengan konsentrasi sebesar $0,137 \mathrm{ppm}$ maka diperoleh $\%$ degradasi sebesar $92,43 \%$.

\section{Kesimpulan}

Berdasarkan hasil penelitian dapat disimpulkan bahwa membran hollow fiber selulosa asetat $-\mathrm{TiO}_{2}$ dapat dibuat dengan metode inversi fasa menggunakan larutan dope dengan perbandingan komposisi selulosa asetat, aseton, dan formamida $(22 \%, 51 \%$, dan $27 \%)$ dan penambahan $\mathrm{TiO}_{2}$ optimal $0,25 \%$ menghasilkan sifat mekanik dengan : nilai tegangan 502,74 $\mathrm{kN} / \mathrm{m}^{2}$, nilai regangan 0,133 dan nilai modulus young sebesar 4781,13 kN/m². Kinerja membran yang optimum terhadap umpan remazol red 198 mempunyai nilai fluks $17,41 \mathrm{~L} / \mathrm{m}^{2}$ jam dan nilai koefisien rejeksi sebesar 91,8\%. Membran hollow fiber selulosa asetat-TiO $\mathrm{T}_{2}$ efektif dalam mendegradasi zat warna remazol red 198 dan limbah pewarna tekstil $92,43 \%$ dan $81,77 \%$.

\section{Saran}

Berdasarkan penelitian yang dilakukan dapat dilakukan optimasi terhadap parameter-parameter lainnya sehingga membran fotokatalitik hollow fiber selulosa asetat- $\mathrm{TiO}_{2}$ lebih efektif untuk pengolahan limbah zat warna tekstil dalam skala industri.

Jiangfeng, Y., Wang, K., Ren, M., Jefferson, Z, L., Wang, H., 2012, Phase Inversion Spinning of Ultrafine Fiber Membranes Through a Single Orifice Spinneret, Original Research Article Jurnal of Membrane Science In Press, Corrected Proof, 87-95.

Karmanto dan Riana Sulistya, 2014, Elektrodekolorisasi Zat Warna Rhemazol Violet 5R Menggunakan Elektroda Grafit, Jurnal Karunia, Vol. 10 No. 1.. 
Mezohegyi, G., van der Zee, F.P., Font, J., Fortuny, A., Fabregat, A., 2012, Towards advanced aqueous dye removal processes: a short review on the versatile role of activated carbon, Jurnal Environment Managing 102, 148-164.

Mulder, M., 2000, Basic Principle of Membrane Technology, Kluwer Academic publisher, Netherland, 167186.

Nakamoto, K., 2009, Infrared and Raman Spectra of Inorganic and Coordination Compounds Part A, Theory and Applications in Inorganic Chemistry, $6^{\text {th }}$ Edition, Canada: John Wiley \& Sons.

Samira, B., Shameli, K., Hamid, S.B.A., 2012, Synthesis and Characterization of Anatase Titanium Dioxide Nanoparticles Using Egg White Solution Via Sol-gel Method, Jurnal of Chemistry, 10, 1155-1160.

Shi, Z., Zhou, M., Zheng, D., Liu, H., Yao, S., 2013, Preparation of Ce-doped $\mathrm{TiO}_{2}$ Hollow Fibers and Their Photocatalytic Degradation Properties for Dye Compound. Journal of The Chinese Chemical Society, 60, 11561162.

Singh, K., Arora, S., 2011, Removal of synthetic textile dyes from wastewaters: a critical review on present treatment technologies, Critic Revisi Analysation Chemistry 4, 807878.
Sukarta, I.N., dan Sumahandriyani, P., 2013, Pengaruh Konsentrasi Ammonium Sulfat $\left(\left(\mathrm{NH}_{4}\right)_{2} \mathrm{SO}_{4}\right)$ Optimasi Jamur Jemari Padi ILS (Isolat Lokal Singaraja) untuk Biodegradasi Zat Warna Azo Jenis Remazol Red, J.Ilmu Kimia, 7, 91100.

Vilar, V. J. P., Malato, S., \& Dionysiou, D. D, 2015, Advanced oxidation technologies: advances and challenges in Iberoamerican countries, Environment Science Pollution Research Institute., 22, 759-761.

Verma, A.K., Dash, R.R., Bhunia, P., 2012, A Review on Chemical Coagulation/Flocculation Technologies for Removal of Color From Textile Wastewaters, Jurnal Environment Managing 93, 154-168.

Wenten I. G., P.T.P. Aryanti, Khoiruddin, 2014, Teknologi Membran dalam Pengolahan Limbah, Teknik Kimia Institut Teknologi Bandung.

Xu, P., Zeng, G.M., Huang, D.L., Feng, C.L., Hu, S., Zhao, M.H., Lai, C., Wei, Z., Huang, C., Xie, G.X., Liu, Z.F., 2012, Use of Iron Oxide Nanomaterials in Wastewater Treatment: a Review, Science Total Environment, 424, 1-10 